\title{
Field of the Dissolved Oil Products Concentration in the Sevastopol Bay Waters (the Black Sea)
}

\author{
P. D. Lomakin*, A. I. Chepyzhenko \\ Marine Hydrophysical Institute of RAS, Sevastopol, Russian Federation \\ *p_lomakin@mail.ru
}

\begin{abstract}
Purpose. The aim of the work is to identify the patterns of the dissolved oil (DO) field structure in the Sevastopol Bay waters and the factors conditioning its state, to compare the obtained result with the available ideas on large-scale distribution of the water quality indicators on the area under study, to evaluate the current trend of the dissolved oil field state, to consider the relationship between the fields of the dissolved oil concentration, the total suspended matter (TSM) and the dissolved organicmatter (DOM).

Methods and Results. Based on the data of a series of the oceanological expeditions carried out by Marine Hydrophysical Institute and Institute of Natural and Technical Systems in 1999-2018, the structure of the dissolved oil content field in the Sevastopol Bay (the Black Sea) and the forming it factors are considered. The obtained result is compared with the known structural regularities of the hydrochemical elements' fields. A tendency of the state of the dissolved oil concentration field is assessed. The relationship between the fields of the dissolved oil concentration, total suspended matter and the dissolved organic matter is considered.

Conclusions. It is shown that the structure of the dissolved oil content field is conditioned by interaction of the polluted waters in the Sevastopol Bay apex (spacious maximum of the substance concentration was revealed in the region of the Neftyanaya Harbor) with the pure Black Sea waters in its western region. The characteristic structural element of the field under investigation is a wellpronounced meridian frontal section observed on the Southern Bay traverse. Significant local maximum values in the dissolved oil field were observed also in the bays Kilen, Korabel'naya, Artilleriyskaya and Severnaya. The frontal section in the dissolved oil concentration field coincided with the boundary section in the hydrochemical elements' fields, which was earlier revealed in course of studying water pollution in the Sevastopol Bay. Noted are the tendency to decrease of the dissolved oil products' concentration in the Southern Bay waters and the qualitative difference of this substance structure being compared to the fields of the total suspended matter and the dissolved organic matter concentrations.
\end{abstract}

Keywords: dissolved oil, dissolved organic matter (DOM), total suspended matter (TSM), Sevastopol Bay, Black Sea.

Acknowledgments: the study was carried out within the framework of the state task on theme No. 0827-2019-0004 "Complex interdisciplinary investigations of the oceanologic processes conditioning functioning and evolution of the Black and Azov seas' coastal zones". The study was performed at financial support of RFBR and Sevastopol within the framework of scientific project No. 18-45-920068.

For citation: Lomakin, P.D. and Chepyzhenko, A.I., 2020. Field of the Dissolved Oil Products Concentration in the Sevastopol Bay Waters (the Black Sea). Physical Oceanography, [e-journal] 27(2), pp. 142-151. doi:10.22449/1573-160X-2020-2-142-151

DOI: $10.22449 / 1573-160 X-2020-2-142-151$

C P. D. Lomakin, A. I. Chepyzhenko, 2020

(C) Physical Oceanography, 2020

\section{Introduction}

Oil products (OP) are among the wide-spread and dangerous substances that pollute the waters of the oceans and seas. Oil and its refined products are an extremely complex, volatile and diverse mixture of substances. From the moment 
the OP enters the aquatic environment, its state is determined by their properties, in particular solubility, which, as a rule, is insignificant at the initial stage of contact with the aquatic environment. However, under conditions of increasing temperature and increasing duration of contact with water, as well as the presence of methyl and methylene groups of hydrocarbons that are part of gasoline, the solubility of OP increases. Their concentration can reach $34 \mathrm{mg} / \mathrm{l}$ [1].

The dissolved OP fraction is adsorbed on suspension. It is resistant and acute toxicity to marine organisms. Aromatic hydrocarbons and polycyclic aromatic hydrocarbons are among the most toxic anthropogenic OP components dissolved in water, which possess carcinogenic properties and have a serious impact on the environment. These substances accumulate in fish tissues and represent a real threat to human health. Therefore, control of the concentration fields of dissolved OPs is a priority in the framework of environmental monitoring of coastal waters [1].

The chemical and spatial stability of dissolved OPs in the aquatic environment makes it possible to determine the sources of their entry into the aquatic environment, propagation paths and accumulation sites according to the results of field research studies [1].

Currently, there is a number of publications [2-6], where issues regarding sources, distribution features, temporal variations in the concentration of dissolved OPs, as well as their relationship with a number of biochemical parameters in the coastal waters of Brazil, Spain, Tunisia, India and the Baltic are considered. Similar studies for the Azov-Black Sea basin have not been found.

The purpose of the present paper is as follows: to reveal the structure patterns of the dissolved OP concentration field and the factors determining it in the Sevastopol Bay water area; to compare the result with known ideas about the distribution of water quality indicators of the studied water area; to evaluate the current trend in the state of the concentration field of a given quantity; to analyze the relationship of the dissolved OP concentration fields with other indicators of the aquatic environment state - the content of total suspended matter (TSM) and dissolved organic matter (DOM).

The object of the present study is the Sevastopol Bay located in the southwest of Crimea. It is zonally oriented and extends into land at a distance of 4.12 miles with a maximum width of 0.83 miles, its average depth is $12 \mathrm{~m}$. The eastern extreme point of the bay is the river estuary. Black, its seaward western part is fenced off from the sea by a pier. The bay is surrounded by numerous smaller-scale bays along the perimeter. On its shores the city of Sevastopol is situated

\section{Initial data and research methods}

As the initial data for analysis, we used the materials of six complex expeditions carried out by Marine Hydrophysical Institute and Institute of Natural and Technical Systems (Sevastopol) for 1999-2018. Over the entire water area of the Sevastopol Bay, in the warm half-year, five surveys were carried out (August and October 2000, July 2001, September 2005 and June 2011). Each survey, which is important for the considered problem, was made according to the same station location scheme (Fig. 1), adopted at the end of the last century for comprehensive studies of the Sevastopol Bay. In December 2018, a survey which partially covered 
the central part of the Sevastopol Bay and mainly related to the Yuzhnaya and Korabel'naya Bays was carried out.

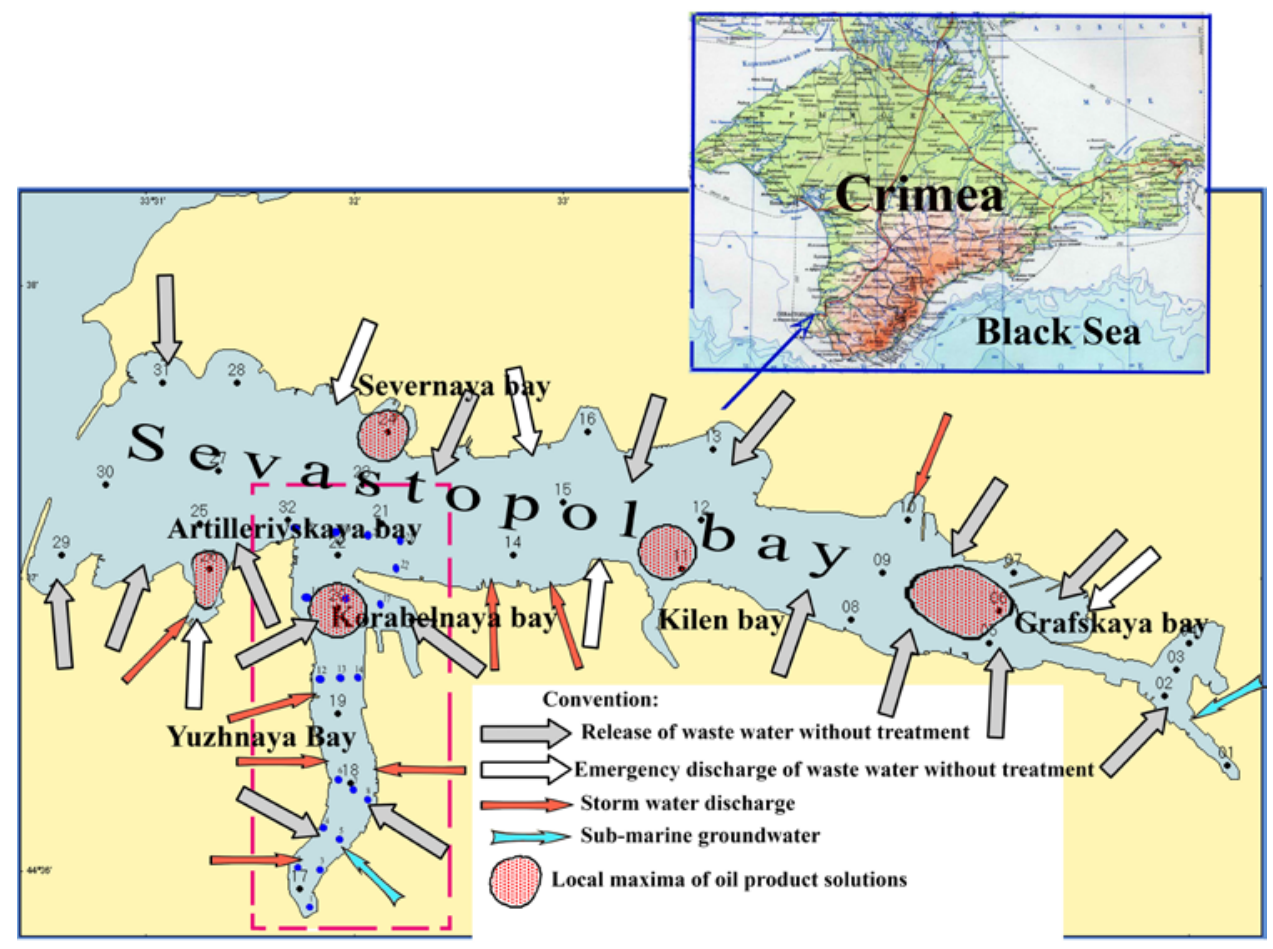

F i g. 1. Geographical location of the Sevastopol Bay; scheme of the oceanological stations, location of the sewage releases [7] and the local maximums of the dissolved oil products' concentrations

Along with the concentration field of oil products dissolved in water, the TSM and DOM content fields are considered in the interpretation of the results. These substances content was determined on the basis of optical methods $[8,9]$ implemented in the Kondor optical biophysical probing complex (hydrobiophysical multiparameter immersion autonomous complex, URL: http://ecodevice.com.ru/ecodevice-catalogue/multiturbidimeter-kondor). By means of this device, arrays of synchronous measurements (in situ) of TSM and DOM contents in a sounding mode with a resolution of $0.1 \mathrm{~m}$ in depth were accumulated and analyzed. Note that the DOM, which characterizes anthropogenic, including bacterial, pollution, is attributed to one of the best water quality indicators in coastal marine and oceanic waters [10-12].

The concentration of oil products dissolved in seawater was determined in laboratory samples of water taken from the sea surface using the traditional UVfluorescence method [13]. This value, presented in relative units, shows how many times the measured OP content exceeds their concentration in unpolluted waters of the central Black Sea, which is taken as a unit.

Water samples were occasionally taken from the surface and from the bottom horizon from the mooring walls and piers in the most polluted places to determine 
the concentration of the test substance from the surface and from the bottom horizon.

\section{Discussion of the results}

Analysis of the materials of each survey revealed a number of general patterns in the nature of the distribution of the analyzed pollutant concentration over the Sevastopol Bay waters. The specific actual fields did not have qualitative differences and reflected the basic laws of the dissolved OP content field structure. The main most widespread maximum of OP concentration was noted in each of them, including a number of less significant local maxima recorded in the same areas of the studied water area. These formations formed a large-scale field structure of the considered element in the entire water area of the Sevastopol Bay.

Timing stability of the main structural features in the content field of the considered element of the aquatic environment in the Sevastopol Bay confirms the opinion [1] on the general conservatism of the dissolved OP concentration fields in the waters of the oceans and seas. Therefore, to illustrate the situation of extreme pollution of the studied water area, a scheme of the maximum concentration of dissolved OP, for which the highest values were selected at each grid node, was calculated. The distribution obtained is shown in Fig. 2.

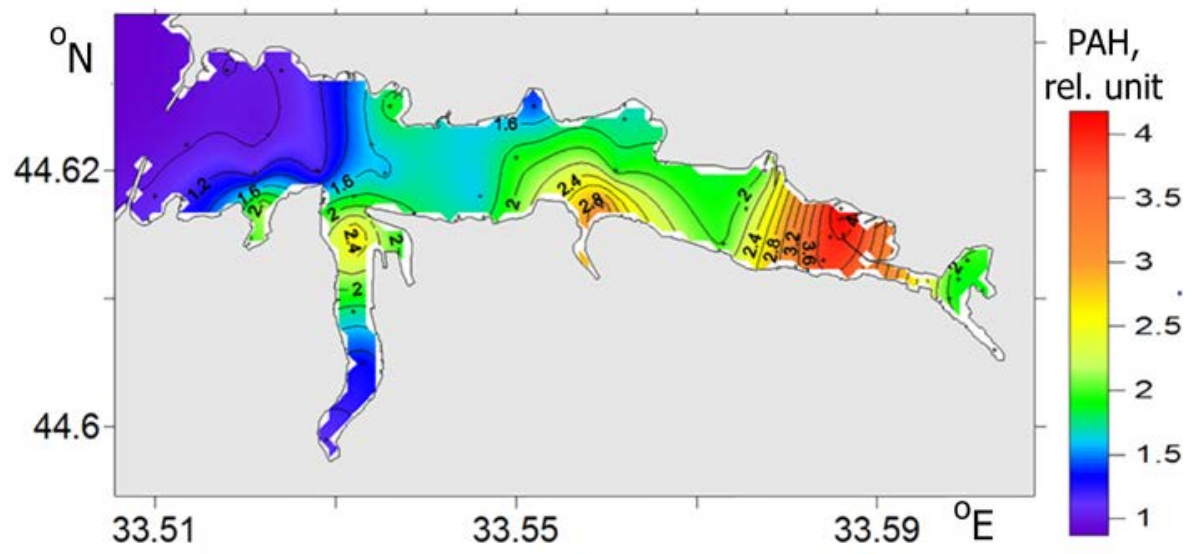

F i g. 2. Maximum concentration of the dissolved oil products in the Sevastopol Bay water upper layer

It can be seen that in various parts of the Sevastopol Bay water area, the maximum content of dissolved OP varied within 1.0-4.2 rel. units. The largescale (within the region) structure of the substance content field was determined by the interaction of the polluted waters of the bay apex with the pure Black Sea waters of its western region.

The main maximum of OP concentration, 4.2 rel. units was observed in the bay apex. Its horizontal scale is estimated at about 1 mile. This extremum mainly determines the background structure of the dissolved OP concentration field in most of the considered water area. Its impact can be traced in a significant area of the Chyornaya river estuary to the Yuzhnaya Bay traverse ( 2 miles, Fig. 2 ). 
This feature of the OP content field is confirmed by the result of the study of hydrocarbon pollution located in the Grafskaya Bay of the Neftyanaya Harbor and adjacent areas [14]. According to this study, the harbor, which has been operating since 1903, has become the main source of oil pollution of the Sevastopol Bay. By the beginning of this century, the pollution degree of water and bottom sediments in the Neftyanaya Harbor area is estimated to be chronic, and OP settled on the bottom migrate towards the sea, polluting shallow water. This result suggests that bottom sediments in the eastern Sevastopol Bay are a powerful secondary source of the dissolved OP fraction.

The lowest OP concentration of open Black Sea waters is characteristic of the western Sevastopol Bay - the water area that communicates with the sea and extends from the main pier to approximately the Yuzhnaya Bay traverse. Here, the background content of dissolved OPs varied within 1.0-1.1 rel. units (Fig. 2).

An important element in the structure of the content field of the considered substance is the meridionally oriented frontal section, located in the Sevastopol Bay on the traverse of the seaward area of the Yuzhnaya Bay. The zonal displacements of this formation cause a significant dynamics in the dissolved OP concentration in the nearby Yuzhnaya, Korabel'naya and Severnaya bays (Fig. 2).

In [15], a zoning scheme for the Sevastopol Bay was proposed according to the level and specificity of the anthropogenic load, where the western area of the bay is allocated, as in our case, to the zone of low pollution. In addition, the eastern boundary of this zone coincides with the frontal section that was identified in the field of dissolved OP content. That is, the studied field structure confirms the prevailing ideas about the large-scale distribution of water quality indicators in the Sevastopol Bay waters.

Significant local maxima of the dissolved OP content of 3.2 and 2.5 rel. units were recorded on approaches to the small Kilen and Korabel'naya bays of. The next most significant local maxima in the Sevastopol Bay water area with a dissolved OP concentration of 2.0 and 1.7 rel. units on the surface and 2.9 and 2.2 rel. units at the bottom (according to observations from the coast) was noted in the Artilleriyskaya and Severnaya bays (Fig. 1, 2).

The high content of dissolved OP in the designated areas is most likely due to their release into the aquatic environment during various types of fleet operation, which corresponds to the main provisions of the study set forth in the monograph [1]. In the considered situation, these are cargo and passenger shipping, cargo and mooring operations and ship repair. According to our observations, local wastewater and storm water do not deliver dissolved OP to the sea.

According to a number of hydrochemical parameters of the environment, the most polluted area of the Sevastopol Bay is traditionally the Yuzhnaya Bay $[7,15]$. This bay is an integral morphometric part of the Sevastopol Bay. It is located in the urban development center. It is oriented along the meridian and between the Nikolaevskiy and Pavlovskiy capes and freely communicates with the Sevastopol Bay. By the water table area, the Yuzhnaya Bay is the second after Sevastopol. It extends into land at a distance of 1.1 miles, the width of its estuarine area is 0.2 miles. Its sea part depth of reaches $18-22 \mathrm{~m}$. In the northeast, a small Korabel'naya Bay extends into the Yuzhnaya one (Fig. 1). 
Observations of the dissolved OP content during the expeditionary studies of the Sevastopol Bay, which were carried out in the Yuzhnaya Bay on an axial section, also recorded situations of obvious pollution of its waters with the studied element concentration up to 2.5 rel. units (Fig. 2).

In December 2018, for the first time, a comprehensive survey was carried out in the Yuzhnaya Bay according to a detailed scheme of the stations. According to this survey results, the bay waters practically did not contain dissolved OP.

The dissolved OP content decrease in the waters of the Yuzhnaya and Korabel'naya bays noted in recent years is largely associated with a technogenic load decrease on the water area of these bays and the Sevastopol Bay as a whole. According to the last (December 2018) survey results, it was shown that at present in these bays there are no more or less significant sources of water pollution by dissolved OP (Fig. 3, $a$ ).

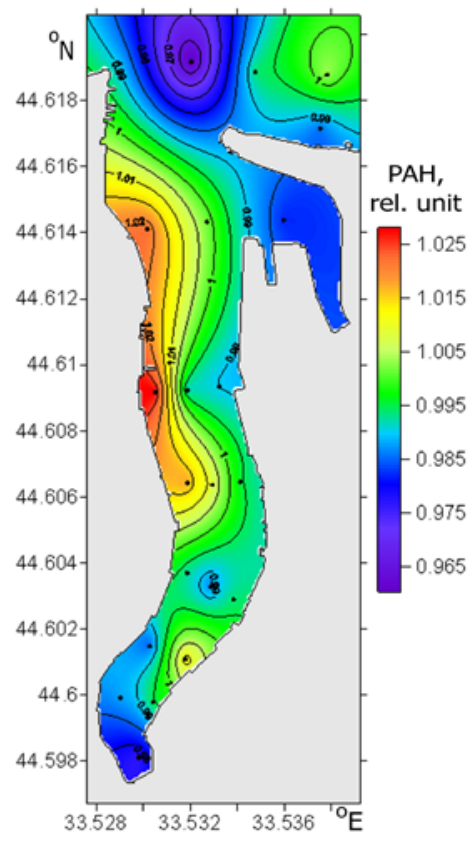

$a$

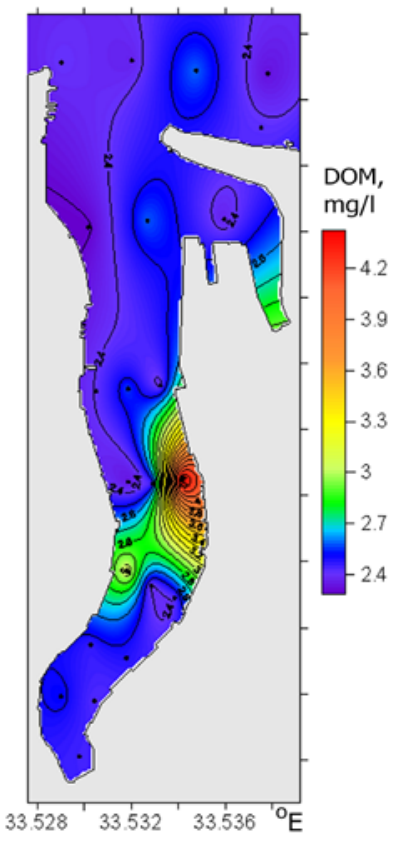

$b$

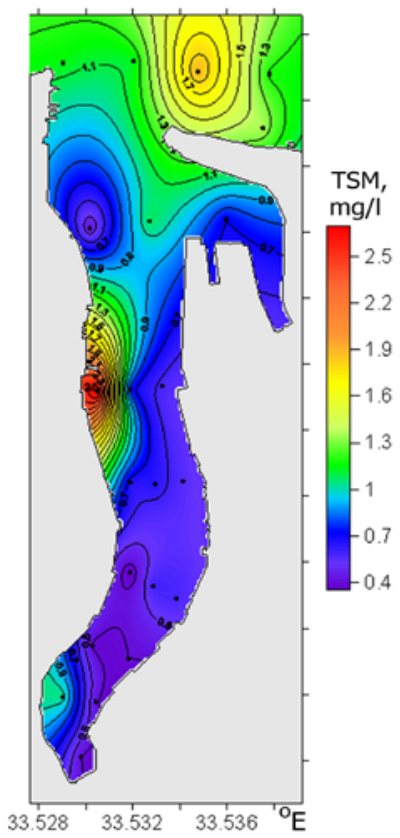

$c$

F i g. 3. Content of the dissolved oil products $-a$, concentration of the dissolved organic matter $-b$, concentration of the total suspended matter $-c$ on the surface of the Yuzhnaya and Korabel'naya bays in December, 2018

In most of the Yuzhnaya and Korabel'naya bays water area in December 2018, the considered OP phase concentration corresponded to their content in the open Black Sea. Numerous local wastewater releases [7] (Fig. 1) practically did not appear in the dissolved OP field. An insignificant concentration of dissolved OP was also observed at the berth walls. The considered element content in close proximity 
to them (30-50 m) was no more than 2-3\% higher than the dissolved OP content in the open Black Sea (Fig. 3, a).

At present, the degree and dynamics of the spatial distribution of dissolved OPs in the Yuzhnaya and Korabel'naya bays is mainly determined by the frontal section position in the content field of the considered element of the aquatic environment, which is located in the Sevastopol Bay and is considered above. Judging by the difference in concentration at the boundaries of this frontal section (Fig. 2), the probable interval of variability of the dissolved OP content in the Yuzhnaya and Korabel'naya bays under modern conditions due to zonal front movements is estimated at 1.0-1.5 rel. units

Unlike the result of the dissolved OP content field analysis, the DOM content field analysis according to December 2018 data did not reveal more or less obvious signs of a decrease in the anthropogenic load on the aquatic environment of the Yuzhnaya and Korabel'naya bays. Here, over the entire water area, the DOM concentration, varied in the range of $2.3-4.5 \mathrm{mg} / \mathrm{l}$, exceeded the natural norm, which, according to [16], was $2 \mathrm{mg} / \mathrm{l}$. Local maxima of the substance content e were noted in the Yuzhnaya Bay apex and at the effluent discharges located off its eastern coast (Fig. 3, b).

The high pollution degree of the Yuzhnaya Bay at the present stage is also confirmed by the TSM content field information data. In December 2018, the bay waters were saturated with a suspension of $1.1-2.7 \mathrm{mg} / \mathrm{l}$. On the western and eastern shores of the Yuzhnaya Bay, in the TSM concentration field, in the wastewater discharge areas, local maxima of $2.5-2.7 \mathrm{mg} / \mathrm{l}$ on the surface and 1.0-1.6 mg/l at the bottom were clearly distinguished (Fig. 3, c). For comparison: in the central Black Sea, the TSM content is an order of magnitude lower and, according to [16], is $0.2 \mathrm{mg} / \mathrm{l}$.

The structure of the TSM and DOM content fields in the Yuzhnaya Bay was qualitatively different from the OP concentration field structure (Fig. 3), which indicates various factors that form these fields. According to the state of TSM and DOM concentration fields, as of December 2018, there were no clear signs of the anthropogenic load decrease in the Yuzhnaya Bay waters. The high content of these elements remaining here corresponds to the result of a study [15] carried out at the beginning of the current century, according to which the Yuzhnaya Bay is the most polluted in comparison with other bays of Sevastopol.

\section{Conclusion}

Based on an analysis of the data of a series of oceanological expeditions (1999-2018), the regularities of the structure of the field of dissolved oil products and its factors in the Sevastopol Bay are considered. The result obtained is compared with the well-known ideas about the large-scale distribution of water quality indicators in this water area. The tendency of the dissolved OP field state was estimated. The relationship between the concentration fields of dissolved OP, TSM and DOM is analyzed.

It was shown that the large-scale (within the considered area boundaries) OP content field structure is determined by the interaction of the polluted waters of 148 
the Sevastopol Bay apex, where a large concentration maximum of this substance was found in the Naftyanaya Harbor area with pure Black Sea waters of its western area. A characteristic structural element of the studied field is a well-defined meridionally oriented frontal section, observed on the Yuzhnaya Bay traverse. The zonal displacements of this formation cause significant variability in the dissolved OP content in the waters located near the Yuzhnaya, Korabel'naya and Severnaya bays. Significant structural elements of the dissolved OP content field include local maxima recorded in the Kilen, Korabel'naya, Artilleriyskaya and Severnaya bays, which is associated with the operation of the fleet.

The frontal section discovered by us in the concentration field of dissolved OPs coincided with the interface in the fields of hydrochemical elements determined in the course of water pollution studies in the Sevastopol Bay, which were carried out by Marine Hydrophysical Institute at the beginning of this century.

A tendency toward the dissolved OP concentration decrease in the Yuzhnaya Bay waters and a qualitative difference in the substance structure compared with the TSM and DOM content fields were revealed.

The high TSM and DOM content the Yuzhnaya Bay corresponds to the prevailing opinion that this bay is the most polluted in comparison with other Sevastopol bays.

\section{REFERENCES}

1. Transportation Research Board and National Research Council, 2003. Oil in the Sea III: Inputs, Fates and Effects. Washington, DC: The National Academies Press. https://doi.org/10.17226/10388

2. Lourenço, R.A., de Oliveira, F.F., de Souza, J.M., Nudi, A.H., Wagener, A.R., Meniconi, M.F.G. and Francioni, E., 2016. Monitoring of Polycyclic Aromatic Hydrocarbons in a Produced Water Disposal Area in the Potiguar Basin, Brazilian Equatorial Margin. Environmental Science and Pollution Research, 23(17), pp. 17113-22. doi: 10.1007/s11356-016-6903-y

3. González, J.J., Viñas, L., Franco, M.A., Fumega, J., Soriano, J.A., Grueiro, G., Muniategui, S., López-Mahía, P., Prada, D., Bayona, J.M., Alzaga, R. and Albaigés, J., 2006. Spatial and Temporal Distribution of Dissolved/Dispersed Aromatic Hydrocarbons in Seawater in the Area Affected by the Prestige Oil Spill. Marine Pollution Bulletin, 53(5-7), pp. 250-259. doi:10.1016/j.marpolbul.2005.09.039

4. $\quad$ Fourati, R., Tedetti, M., Guigue, C., Goutx, M., Garcia, N., Zaghden, H., Sayadi, S. and Elleuch, B., 2018. Sources and Spatial Distribution of Dissolved Aliphatic and Polycyclic Aromatic Hydrocarbons in Surface Coastal Waters of the Gulf of Gabès (Tunisia, Southern Mediterranean Sea). Progress in Oceanography, 163, pp. 232247. doi:10.1016/j.pocean.2017.02.001

5. Sundaraarajan, S., Karthikeyan, R. and Khadanga, M.K., 2016. Spatial Distribution of Polycyclic Aromatic Hydrocarbons in Ennore Estuary and Coastal Waters, Chennai, India. Asian Journal of Chemistry, 28(1), pp. 35-38. doi:10.14233/ajchem.2016.19160

6. Pikkarainen, A-L. and Lemponen, P., 2005. Petroleum Hydrocarbon Concentrations in Baltic Sea Subsurface Water. Boreal Environment Research, 10, pp. 125-134. 
Available at: http://www.borenv.net/BER/pdfs/ber10/ber10-125.pdf [Accessed: 24 April 2020].

7. Sovga, E.E., Mezentseva, I.V., Khmara, T.V. and Slepchuk, K.A., 2014. [On the Prospects and Possibilities of Assessing the Self-Cleaning Capacity of the Sevastopol Bay Water Area]. In: MHI, 2014. Ekologicheskaya Bezopasnost' Pribrezhnykh i Shel'fovykh Zon i Kompleksnoe Ispol'zovanie Resursov Shel'fa [Ecological Safety of Coastal and Shelf Zones and Comprehensive Use of Shelf Resources]. Sevastopol: ECOSI-Gidrofizika. Iss. 28, pp. 153-164 (in Russian).

8. Chepyzhenko, A.A. and Chepyzhenko, A.I., 2017. Methods and Device for In Situ Total Suspended Matter (TSM) Monitoring in Natural Waters' Environment. In: SPIE, 2017. Proceedings SPIE 10466. 23rd International Symposium on Atmospheric and Ocean Optics: Atmospheric Physics, $104663 \mathrm{G}$. doi:10.1117/12.2287127

9. Chepyzhenko A.I., Chepyzhenko A.A., 2017. Methods and Device for in situ Dissolved Organic Matter (DOM) Monitoring in Natural Waters' Environment. In: Proc. SPIE 10466, 23rd International Symposium on Atmospheric and Ocean Optics: Atmospheric Physics, 104663S (30 November 2017). doi: $10.1117 / 12.2287797$

10. Boss, E., Pegau, W.S., Zaneveld, J.R.V. and Barnard, A.H., 2001. Spatial and Temporal Variability of Absorption by Dissolved Material at a Continental Shelf. Journal of Geophysical Research: Oceans, 106(C5), pp. 9499-9507. doi:10.1029/2000JC900008

11. Tedetti, M., Longhitano, R., Garcia, N., Guigue, C., Ferretto, N. and Goutx, M., 2012. Fluorescence Properties of Dissolved Organic Matter in Coastal Mediterranean Waters Influenced by a Municipal Sewage Effluent (Bay of Marseilles, France). Environmental Chemistry, 9(5), pp. 438-449. doi:10.1071/EN12081

12. Karlsson, C.M.G., Cerro-Gálvez, E., Lundin, D., Karlsson, C., Vila-Costa, M. and Pinhassi, J., 2019. Direct Effects of Organic Pollutants on the Growth and Gene Expression of the Baltic Sea Model Bacterium Rheinheimera sp. BAL 341. Microbial Biotechnology, 12(5), pp. 892-906. doi:10.1111/1751-7915.13441

13. Holdway, D., Radlinski, A., Exon, N. Auzende, J-M. and Van de Beuque, S., 2000. Continuous Multi-Spectral Fluorescence and Absorption for Petroleum Hydrocarbon Detection in Near-Surface Ocean Waters: ZoNeC05 Survey, Fairway Basin area, Lord Howe Rise. Record 2000/35. Canberra: Australian Geological Survey Organization, $57 \quad$ p. Available https://d28rz98at9flks.cloudfront.net/34232/Rec2000_035.pdf [Accessed: 115 April 2020].

14. Alyomov, S.V., 2009. Ecological Quality Assessment of Port Aquatoria in Sevastopol Region by Use of Macrobenthic Community Characteristics. In: MHI, 2009. Ekologicheskaya Bezopasnost' Pribrezhnykh i Shel'fovykh Zon i Kompleksnoe Ispol'zovanie Resursov Shel'fa [Ecological Safety of Coastal and Shelf Zones and Comprehensive Use of Shelf Resources]. Sevastopol: ECOSI-Gidrofizika. Iss. 18, pp. 19-29 (in Russian).

15. Ivanov, V.A., Ovsyany, E.I., Repetin, L.N., Romanov, A.S. and Ignatyeva, O.G., 2006. Hydrological and Hydrochemical Regime of the Sevastopol Bay and Its Changing under Influence of Climatic and Anthropogenic Factors. Preprint. Sevastopol: MHI NAS of Ukraine, 90 p. Available at: http://mhi- 
ras.ru/assets/files/gidrologo-

gidrohimicheskij_rezhim_sevastopolskoj_buhty_2006.pdf [Accessed: 05 April 2020].

16. Khailov, K.M., 1971. [Ecological Metabolism in the Sea]. Kiev: Naukova Dumka, 252 p. (in Russian).

About the authors:

Pavel D. Lomakin, Leading Research Associate, Marine Hydrophysical Institute of RAS (2 Kapitanskaya St., Sevastopol, Russian Federation, 299011), Ph. D. (Geogr.), Professor, ResearcherID: V-7761-2017, p_lomakin@mail.ru

Alexey I. Chepyzhenko, Senior Research Associate, Marine Hydrophysical Institute of RAS (2 Kapitanskaya St., Sevastopol, 299011, Russian Federation), Ph. D. (Tеch. Sci.), SPIN-код: 35999653, Scopus Author ID: 6504344211, ecodevice@yandex.ru

Contribution of the authors:

Two authors carried out planning, carrying out and direct participation in all the expeditions and interpretation of the results together.

Alexey I. Chepyzhenko carried out all the observations, completed the primary information processing and prepared figures for the article.

Pavel D. Lomakin carried out an analysis of the synoptic situation and weather conditions that accompanied the expeditionary research and prepared the text of the article.

All the authors have read and approved the final manuscript.

The authors declare that they have no conflict of interest. 